\title{
Atypical hemolytic uremic syndrome with $M C P$ mutations preceded by respiratory infection
}

\author{
Keiko Yasuda $\cdot$ Koichi Sasaki $\cdot$ Masaya Yamato • \\ Hiromi Rakugi $\cdot$ Yoshitaka Isaka · Terumasa Hayashi • \\ Rossella Piras • Elena Bresin
}

Received: 26 March 2012/ Accepted: 5 September 2012/Published online: 5 October 2012

(C) Japanese Society of Nephrology 2012

\begin{abstract}
A 14-year-old boy was referred to our hospital with general fatigue and sore throat. A chest X-ray and computed tomography revealed diffuse bilateral bronchitis. A laboratory examination showed anemia, thrombocytopenia, and renal insufficiency. He had a past medical history of hemolytic uremic syndrome (HUS) without diarrhea at the age of 3; moreover, his elder brother suffered from HUS at the age of 12 . These findings indicated that the patient had a familial relapsing form of HUS (atypical HUS). Therefore, he was immediately treated with plasma exchange (PE), as suggested by guidelines, obtaining complete remission. Fifteen months later, he suffered another relapse of atypical HUS preceded by respiratory infection and was cured again with PE. His ADAMTS-13 activity was normal and its inhibitory antibody was undetectable. Two different mutations were found in the gene encoding membrane cofactor protein (MCP). Respiratory infections preceded all three episodes of HUS, but we
\end{abstract}

K. Yasuda $\cdot$ K. Sasaki $\cdot$ M. Yamato

Department of Nephrology, Rinku General Medical Center,

Osaka, Japan

K. Yasuda $(\bowtie) \cdot$ H. Rakugi · Y. Isaka

Department of Geriatric Medicine and Nephrology, Osaka

University Graduate School of Medicine, B6, 2-2 Yamada-oka,

Osaka 587-871, Japan

e-mail: k-yasuda@rgmc.izumisano.osaka.jp;

k-yasuda@kid.med.osaka-u.ac.jp

T. Hayashi

Department of Kidney Disease and Hypertension, Osaka General

Medical Center, Osaka, Japan

R. Piras · E. Bresin

Mario Negri Institute for Pharmacological Research, Clinical Research Center for Rare Diseases Aldo e Cele Daccò, Ranica (Bergamo), Italy could not detect the pathogenic agent. Although the longterm outcomes of patients with atypical HUS who have mutations in the $M C P$ gene appear favorable, recurrences are nevertheless frequent. Few reports have described Japanese patients with atypical HUS and complement regulatory abnormalities. This is the first report of a Japanese patient with atypical HUS and mutations in the $M C P$ gene.

Keywords Atypical hemolytic uremic syndrome . Membrane cofactor protein - Mutations

\section{Introduction}

Mutations in the gene encoding membrane cofactor protein (MCP) have been identified in $10-15 \%$ of patients with atypical hemolytic uremic syndrome (HUS) [1]. Although the long-term outcome appears favorable in these patients, with $80 \%$ remaining dialysis-free, recurrences are nevertheless frequent [1]. Guidelines suggest that plasma therapy should be started within $24 \mathrm{~h}$ after diagnosis, without waiting for the results of definitive investigations such as genetic tests [2]. However, plasma therapy should not be useful in patients with $M C P$ mutations, since MCP is a membrane-bound protein [3]. Our patient was effectively treated with plasma exchange (PE) before he was found to be heterozygous for two mutations in the $M C P$ gene. There are many reports of atypical HUS patients all over the world, as well as many reports of genetic complement abnormalities associated with atypical HUS, especially in Europe. However, few reports have described Japanese patients with atypical HUS and complement abnormalities [4]. This is the first report of a Japanese patient with atypical HUS and two mutations in the $M C P$ gene. 


\section{Case report}

A 14-year-old Japanese boy was referred to our hospital with general fatigue and sore throat. Chest X-ray and computed tomography (CT) revealed diffuse bilateral bronchitis. Laboratory evaluation (Table 1) showed elevated serum creatinine concentration $(3.32 \mathrm{mg} / \mathrm{dL})$, anemia (hemoglobin $12.8 \mathrm{~g} / \mathrm{dL}$ ), thrombocytopenia (platelets $7.1 \times 10^{4} / \mu \mathrm{L}$ ), and schistocytosis. A search for Shiga toxin producing Escherichia coli (STEC) using PCR in the stool sample was negative. He had developed HUS without diarrhea at the age of three, and his two-year older brother had developed HUS at the age of 12. On the basis of these findings, a diagnosis of atypical HUS was made. Plasma exchange was immediately performed because of fast progressive hemolytic anemia and renal insufficiency. After four consecutive days of PE, his platelet count increased and his renal function recovered. At that time, his ADAMTS-13 activity was normal and its inhibitory antibody was undetectable. The activity of complement factor $\mathrm{H}$ was also normal and its inhibitory antibody was undetectable.

Fifteen months later, the patient was referred to our hospital for a new relapse of atypical HUS, with general fatigue and sore throat, again preceded by respiratory infection. Laboratory findings (Table 2) revealed elevated serum creatinine $(3.19 \mathrm{mg} / \mathrm{dL})$, anemia (hemoglobin $12.5 \mathrm{~g} / \mathrm{dL}$ ), and thrombocytopenia (platelets $5.9 \times 10^{4} / \mu \mathrm{L}$ ).

Table 1 Laboratory data on admission

\begin{tabular}{|c|c|c|}
\hline \multirow{3}{*}{$\begin{array}{l}\text { CBC: } \\
\text { WBC } 13180 / \mu \mathrm{L} \\
(\text { neu. } 87.0 \%, \text { eo. } 1.1 \% \text { ) }\end{array}$} & \multicolumn{2}{|l|}{ Blood chemistry: } \\
\hline & T-bil $5.2 \mathrm{mg} / \mathrm{dL}$ & $\mathrm{CRP} 6.0 \mathrm{mg} / \mathrm{dL}$ \\
\hline & D-bil $0.2 \mathrm{mg} / \mathrm{dL}$ & PT $75 \%$ \\
\hline $\mathrm{RBC} 432 \times 10^{4} / \mu \mathrm{L}$ & AST 55 IU/L & PT(INR) 1.25 \\
\hline $\mathrm{Hb} 12.8 \mathrm{~g} / \mathrm{dl}$ & ALT 9 IU/L & APTT $27.8 \mathrm{~s}$ \\
\hline Plt $7.1 \times 10^{4} / \mu \mathrm{L}$ & $\begin{array}{l}\text { LDH } 1756 \text { IU/L } \\
\text { CK } 319 \mathrm{IU} / \mathrm{L}\end{array}$ & D-dimer $4.00 \mu \mathrm{g} / \mathrm{mL}$ \\
\hline Urinalysis: & $\mathrm{Cr} 3.32 \mathrm{mg} / \mathrm{dL}$ & Serology: \\
\hline Specific gravity 1.020 & BUN 45.7 mg/dL & CH50 $32.2 \mathrm{U} / \mathrm{mL}$ \\
\hline pH 5.0 & $\mathrm{TP} 6.3 \mathrm{~g} / \mathrm{dL}$ & C3 $71 \mathrm{mg} / \mathrm{dL}$ \\
\hline Prot $(3+)$ & Alb $3.5 \mathrm{~g} / \mathrm{dL}$ & $\mathrm{C} 47 \mathrm{mg} / \mathrm{dL}$ \\
\hline Glucose (-) & T-chol $146 \mathrm{mg} / \mathrm{dL}$ & ANA 40 \\
\hline Occult blood $(3+)$ & $\mathrm{Na} 136 \mathrm{mEq} / \mathrm{L}$ & $\begin{array}{l}\text { ADAMTS-13 activity } \\
64.2 \%\end{array}$ \\
\hline RBC $124.7 / \mathrm{HPF}$ & $\mathrm{K} 5.7 \mathrm{mEq} / \mathrm{L}$ & $\begin{array}{l}\text { ADAMTS-13 antibody } \\
<0.5 \text { Bethesda unit/L }\end{array}$ \\
\hline $\mathrm{Cr} 326 \mathrm{mg} / \mathrm{dL}$ & $\mathrm{Cl} 100 \mathrm{mEq} / \mathrm{L}$ & $\mathrm{IgG} 761 \mathrm{mg} / \mathrm{dL}$ \\
\hline $\mathrm{UN} 279 \mathrm{mg} / \mathrm{dL}$ & $\mathrm{Ca} 8.9 \mathrm{mg} / \mathrm{dL}$ & $\mathrm{IgM} 64.9 \mathrm{mg} / \mathrm{dL}$ \\
\hline $\mathrm{Na} 34.0 \mathrm{mEq} / \mathrm{L}$ & $\mathrm{P} 4.5 \mathrm{mg} / \mathrm{dL}$ & HBsAg $(-)$ \\
\hline & & $\operatorname{HCVAb}(-)$ \\
\hline & & TPAb $(-)$ \\
\hline & & RPR (-) \\
\hline
\end{tabular}

Chest X-ray and CT showed diffuse bilateral bronchitis; these images were similar to those obtained during the previous episode of HUS. We knew that he had neither ADAMTS-13 inhibitory antibody nor factor $\mathrm{H}$ inhibitory antibody, so fresh frozen plasma (FFP) transfusion was performed on the first day of admission to the hospital. However, renal insufficiency led to oliguria, and his respiratory status worsened. We therefore decided to perform PE, since the FFP transfusion had led to volume expansion. A four-day course of $\mathrm{PE}$ was effective at increasing his platelet count and improving renal function.

It is known that infection can trigger atypical HUS episodes. Common infectious events such as upper respiratory tract infections or gastroenteritis appear to trigger HUS episodes in approximately two-thirds of atypical HUS patients $[4,5]$. The occurrence of atypical HUS after specific bacterial or viral infections is exceptional. Respiratory infection preceded all three HUS manifestations in our patient. We therefore attempted to investigate the trigger for his respiratory infection. However, sputum cultures, influenza virus A and B antigens, respiratory syncytial virus, parainfluenza virus and adenovirus antibodies, measles virus RNA, human herpes virus 6 DNA, and cytomegalovirus DNA were all negative.

We also investigated the presence of genetic complement abnormalities in the DNA of the patient, identifying two heterozygous mutations in the short consensus repeats (SCRs) 1-4 of MCP, the hotspot mutation region of this

Table 2 Laboratory data when he suffered atypical HUS 15 months later

\begin{tabular}{|c|c|c|}
\hline CBC: & $\begin{array}{l}\text { Blood } \\
\text { chemistry: }\end{array}$ & \\
\hline WBC $14340 / \mu \mathrm{L}$ & T-bil $3.7 \mathrm{mg} / \mathrm{dL}$ & CRP $2.6 \mathrm{mg} / \mathrm{dL}$ \\
\hline (neu. $90.0 \%$, eo. $1.1 \%$ ) & D-bil $0.2 \mathrm{mg} / \mathrm{dL}$ & PT $78 \%$ \\
\hline $\mathrm{RBC} 405 \times 10^{4} / \mu \mathrm{L}$ & AST 74 IU/L & PT(INR) 1.18 \\
\hline $\mathrm{Hb} 12.5 \mathrm{~g} / \mathrm{dl}$ & ALT 7 IU/L & APTT $29.5 \mathrm{~s}$ \\
\hline Plt $5.9 \times 10^{4} / \mu \mathrm{L}$ & $\begin{array}{l}\text { LDH } 1986 \text { IU/L } \\
\text { CK } 231 \mathrm{IU} / \mathrm{L}\end{array}$ & D-dimer $19.50 \mu \mathrm{g} / \mathrm{mL}$ \\
\hline Urinalysis: & $\mathrm{Cr} 3.19 \mathrm{mg} / \mathrm{dL}$ & Serology: \\
\hline Specific gravity 1.025 & BUN $42.9 \mathrm{mg} / \mathrm{dL}$ & CH50 $26.2 \mathrm{U} / \mathrm{mL}$ \\
\hline $\mathrm{pH} 6.0$ & $\mathrm{TP} 6.3 \mathrm{~g} / \mathrm{dL}$ & C3 $82 \mathrm{mg} / \mathrm{dL}$ \\
\hline Protein $(3+)$ & Alb $3.9 \mathrm{~g} / \mathrm{dL}$ & $\mathrm{C} 48 \mathrm{mg} / \mathrm{dL}$ \\
\hline Glucose (-) & T-chol $180 \mathrm{mg} / \mathrm{dL}$ & ANA 40 \\
\hline \multirow[t]{6}{*}{ Occult blood $(3+)$} & $\mathrm{Na} 139 \mathrm{mEq} / \mathrm{L}$ & $\begin{array}{l}\text { ADAMTS-13 } \\
\text { activity } 87 \%\end{array}$ \\
\hline & $\mathrm{K} 4.6 \mathrm{mEq} / \mathrm{L}$ & $\begin{array}{l}\text { ADAMTS- } 13 \text { antibody } \\
<0.5 \text { Bethesda unit } / \mathrm{L}\end{array}$ \\
\hline & $\mathrm{Cl} 103 \mathrm{mEq} / \mathrm{L}$ & HBsAg (-) \\
\hline & $\mathrm{Ca} 9.1 \mathrm{mg} / \mathrm{dL}$ & $\operatorname{HCVAb}(-)$ \\
\hline & P $3.7 \mathrm{mg} / \mathrm{dL}$ & TPAb $(-)$ \\
\hline & & RPR (-) \\
\hline
\end{tabular}


gene. A new heterozygous deletion of $4 \mathrm{pb}(\mathrm{c} .475+1$ 4delGTAA), predicted by GENSCAN web server (http:// genes.mit.edu/GENSCAN.html) to delete seven aminoacids and change the eighth aminoacid, was found in the intronic region of SCR2. Moreover, a previously described heterozygous c.565T $>\mathrm{G}$ missense mutation, leading to the aminoacid substitution Tyr189Asp [7], was identified in the SCR3 of $M C P$. The sequences of complement factors $\mathrm{H}$ $(\mathrm{CFH}), \mathrm{I}, \mathrm{C} 3$, and of the thrombomodulin genes were normal, as were the levels of $\mathrm{CFH}$ antigen and activity.

\section{Discussion}

HUS is characterized by nonimmune hemolytic anemia, thrombocytopenia, and renal impairment [8]. Approximately $10 \%$ of all HUS cases are classified as atypical, since they are not caused by Stx-producing bacteria or streptococci [8, 9]. Atypical HUS has a poor prognosis, with death rates as high as $25 \%$ [9] and progression to end-stage renal disease in half of the patients $[8,10]$. During the past decade, multiple genetic abnormalities associated with atypical HUS have been described [1]. Less than $20 \%$ of all atypical HUS cases are familial [1]. Atypical HUS that develops in patients without a family history of the disease is classified as sporadic. Triggers for the sporadic form include infection by the human immunodeficiency virus, cancer, organ transplantation, pregnancy, and the use of certain anticancer drugs, immunotherapeutic agents (e.g., cyclosporine and tacrolimus), and antiplatelet agents (e.g., ticlopidine and clopidogrel) [11-13].

Complement regulatory abnormalities, either inherited or acquired through autoantibodies, are frequent causes of atypical HUS [6]. In patients with atypical HUS, a variety of mutations in members of the complement alternative pathway have been described, accounting for $50-60 \%$ of cases [1]. Mutations in the $M C P$ gene have been identified in 10-15\% of patients with atypical HUS [1]. Obtaining an etiologic diagnosis should help the patient to get better clinical advice and treatment. In the first week after disease presentation, clinicians usually do not have the results of definitive investigations such as genetic tests and plasma concentrations of complement factors and ADAMTS13 activity/antibody. Therefore, clinicians must decide empirically whether to implement initial treatment such as plasma therapy. According to the guidelines, the first plasma therapy (plasma exchange, 1-2 plasma volumes/ day; plasma infusion, $20-30 \mathrm{ml} / \mathrm{kg} / \mathrm{day}$ ) should be instituted as soon as it is practicable within $24 \mathrm{~h}$ of diagnosis [2]. However, the atypical HUS patients who should benefit most from plasma treatment are those with mutations in plasma proteins, such as CFH and CFI. Overall, the published data $[14,15]$ on patients with $\mathrm{CFH}$ mutations show either complete or partial (hematological normalization with renal sequelae) remission in around $60 \%$ of plasmatreated episodes. Patients with CFI mutations show a partial response to plasma, and remission is achieved in about $30-40 \%$ of treated episodes [14, 15]. However, patients with isolated MCP (CD46) dysfunction do not appear to benefit from plasma therapy $[3,4,6]$. This may be because MCP is a membrane-bound complement regulator, not a circulating one, and there is a high spontaneous remission rate. In fact, the patient's elder brother also suffered from atypical HUS when he was 12 years old, and he was cured without plasma therapy.

Moreover, plasmapheresis is not without risk [16]. The justification for urgent treatment when the etiological diagnosis is unknown is the high risk of early death, irreversible kidney damage, or the risks associated with prolonged disease activity [5, 6]. Recently, eculizumab (a humanized monoclonal antibody against C5) has been demonstrated to be effective in the management of atypical HUS refractory to plasma therapy $[17,18]$.

Our patient was diagnosed with atypical relapsing HUS and treated with plasma therapy. The presence of two $M C P$ mutations was subsequently demonstrated, and this is the first published report of a Japanese patient with atypical HUS and mutations in the $M C P$ gene. Obtaining an etiological diagnosis should avoid the need for excess treatment, such as plasma therapy, in this patient, who could benefit from conservative treatment alone in the future. In addition, we were able to inform the patient and his family that his long-term renal outcome should be good. However, another goal for this patient was to avoid recurrences. Respiratory infections preceded all three manifestations of his HUS. Detecting the trigger for his respiratory infection may help to elucidate the mechanism of his HUS recurrence.

Acknowledgments We gratefully acknowledge Dr. Yoshihiko Hidaka (Department of Pediatrics, Shinshu University School of Medicine) for measuring the $\mathrm{CFH}$ antigen and activity levels. We also thank Dr. Yoshihiro Fujimura and Dr. Masanori Matsumoto (Department of Blood Transfusion Medicine, Nara Medical University) for measuring ADAMTS-13 activity inhibitory antibody. Dr. Rossella Piras received a fellowship from Fondazione ART per la Ricerca sui Trapianti ONLUS, Milan, Italy, and from Fondazione Aiuti per la Ricerca sulle Malattie Rare, Bergamo, Italy.

\section{References}

1. Noris M, Remuzzi G. Atypical hemolytic-uremic syndrome. N Eng J Med. 2009;361:1676-87.

2. Ariceta G, Besbas N, Johnson S, Karpman D, Landau D, Loirat $\mathrm{C}$, et al. Guideline for the investigation and initial therapy of diarrhea-negative hemolytic uremic syndrome. Pediatr Nephrol. 2009;24:687-96.

3. Davin JC, Buter N, Groothoff J, van Wijk J, Bouts A, Strain L, et al. Prophylactic plasma exchange in CD46-associated atypical haemolytic uremic syndrome. Pediatr Nephrol. 2009;24:1757-60. 
4. Matsukuma E, Gotoh Y, Kuroyanagi Y, Yamada T, Iwasa M, Yamakawa $\mathrm{S}$, et al. A case of atypical hemolytic uremic syndrome due to anti-factor $\mathrm{H}$ antibody in a patient presenting with a factor XII deficiency identified two novel mutations. Clin Exp Nephrol. 2011;15:269-74.

5. Caprioli J, Noris M, Brioschi S, Pianetti G, Castelletti F, Battinaglio $\mathrm{P}$, et al. Genetics of HUS: the impact of $\mathrm{MCP}, \mathrm{CFH}$, and IF mutations on clinical presentation, response to treatment, and outcome. Blood. 2006;108:1267-79.

6. Sellier-Leclerc AL, Fremeaux-Bacchi V, Dragon-Durey MA, Macher MA, Niaudet P, Guest G, et al. Differential impact of complement mutations on clinical characteristics in atypical hemolytic uremic syndrome. J Am Soc Nephrol. 2007;18: 2392-400.

7. Fremeaux-Bacchi V, Moulton EA, Kavanagh D, Dragon-Durey MA, Blouin J, Caudy A, et al. Genetic and functional analyses of membrane cofactor protein (CD46) mutations in atypical hemolytic uremic syndrome. J Am Soc Nephrol. 2006;17:2015-7.

8. Noris M, Remuzzi G. Hemolytic uremic syndrome. J Am Soc Nephrol. 2005;16:1035-50.

9. Kaplan BS, Meyers KE, Schulman SL. The pathogenesis and treatment of hemolytic uremic syndrome. J Am Soc Nephrol. 1998;9:1126-33.

10. Constantinescu AR, Bitzan M, Weiss LE, Christen E, Kaplan BS, Cnaan A, et al. Non-enteropathic hemolytic uremic syndrome (HUS). Pediatr Nephrol. 2008;23:1749-60.
11. Besbas N, Karpman D, Landau D, Loirat C, Proesmans W, Remuzzi $\mathrm{G}$, et al. A classification of hemolytic uremic syndrome and thrombotic thrombocytopenic purpura and related disorders. Kidney Int. 2006;70:423-31.

12. Ruggenenti P, Noris M, Remuzzi G. Thrombotic microangiopathy hemolytic uremic syndrome, and thrombotic thrombocytopenic purpura. Kidney Int. 2001;60:831-46.

13. Zakarija A, Bennett C. Drug-indused thrombotic microangiopathy. Semin Thromb Hemost. 2005;31:681-90.

14. Noris M, Caprioli J, Bresin E, Mossali C, Pianetti G, Gamba S, et al. Relative role of genetic complement abnormalities in sporadic and familial aHUS and their impact on clinical phenotype. Clin J Am Soc Nephrol. 2010;5:1844-59.

15. Sellier-Leclerc AL, Fremeaux-Bacchi V, Dragon-Durey MA, Macher MA, Niaudet P, Guest G, et al. Differential impact of complement mutations on clinical characteristics in atypical hemolytic uremic syndrome. J Am Soc Nephrol. 2007;18: 2392-400.

16. Michon B, Moghrabi A, Winikoff R, Barrette S, Bernstein ML, Champagne J, et al. Complications of apheresis in children. Transfusion. 2007;47:1837-42.

17. Gruppo RA, Rother RP. Eculizumab for congenital atypical hemolytic-uremic syndrome. N Engl J Med. 2009;360:544-6.

18. Nürnberger J, Philipp T, Witzke O, Opazo Saez A, Vester U, et al. Eculizumab for atypical hemolytic-uremic syndrome. N Engl J Med. 2009;360:542-4. 